\title{
Edaphic and Foliar Biofortification of Common Black Bean (Phaseolus vulgaris L.) with Iron
}

\author{
J.W. Felix¹, E. Sánchez-Chávez², E. de-la-Cruz-Lázaro', C. Márquez-Quiroz
}

10.18805/LR-553

\begin{abstract}
Background: Biofortification is the process by which the nutritional quality of food crops is improved through agronomic practices, conventional plant breeding, or modern biotechnology. The objective in this work was to determine the effect of iron on mineral content, proximal composition, bioactive compound content and antioxidant activity in the bean grain.

Methods: In this present work, we biofortificated plants of common bean (Phaseolus vulgaris L.), with doses of iron sulfate $(0,0.25$ and $0.50 \mathrm{~g})$ and foliar iron chelate $(0,25,50$ and $100 \mu \mathrm{M})$. In the grain content mineral (iron, zinc, copper and nickel), proximal composition (moisture, ash, crude fiber, fat, protein, carbohydrates and energy), total phenols, flavonoids, anthocyanins and antioxidant activity were determined.

Result: Edaphic and foliar biofortification increased iron content in the grain. All treatment combinations containing some edaphic or foliar doses of iron increased levels of ash fat, protein, crude fiber, total phenols and anthocyanins, and decreased carbohydrate content and energy. Nine treatment combinations, including the control, possessed the highest antioxidant activities (84.96-89.76\%).
\end{abstract}

Key words: Anthocyanins, Antioxidant activity, Bioactive compounds, Crude fiber, Phenols, Protein.

\section{INTRODUCTION}

Plants are the main source of iron the human diet and provide nutrition directly, as a staple food or vegetables item, or indirectly, as fodder for animals. Biofortification is an approach that has the potential to be sustainable in the long term. It can be used as an economically efficient and effective means to increase the mineral content within the edible portions of plants (Connorton and Balk, 2019). Biofortification programs focus on increasing the iron, zinc, selenium and vitamin A content. The programs complement and sometimes replace, fortification or chemical supplementation with minerals (Rani et al., 2019). Iron deficiency affects over $30 \%$ of the world's population and, disproportionately harms women, children and babies (Nissar et al., 2019).

In Mexico, Black beans contain an average of $52 \mathrm{mg} /$ $\mathrm{kg}$ iron, with varies between 24.8 and $57.5 \mathrm{mg} / \mathrm{kg}$ (ChávezMendoza and Sánchez, 2017). These high levels of iron are advantageous because they facilitate the biofortification process. Reports have shown that iron contained within beans increased after biofortification via edaphic and foliar application, however, fortification with chelated iron was most efficient (Sida-Arreola et al., 2015). Harvest Plus reported that the goal of iron-bean biofortification programs was to produce beans containing $94 \mathrm{mg} / \mathrm{kg}$ (Sperotto and Ricachenevsky, 2017). However, biofortification of beans has been limited by the low bioavailability of iron that is associated with antinutrient content, such as polyphenols and phytates, which function as inhibitors of iron utilization (Petry et al., 2014). Therefore, improving our understanding of how these factors interact to influence grain iron accumulation is vital for enriching iron concentrations in food grain (Shukla and Lata, 2018). Therefore, the objective of
'División Académica de Ciencias Agropecuarias, Universidad Juárez Autónoma de Tabasco. Km. 25. Carretera VillahermosaTeapa. CP. 86290. Centro, Tabasco, México.

${ }^{2}$ Centro de Investigación en Alimentación y Desarrollo, Unidad Delicias. Av. Cuarta Sur, CP. 33089, Fracc. Vencedores del Desierto, Ciudad Delicias, Chihuahua, México.

Corresponding Author: E. de-la-Cruz-Lázaro, División Académica de Ciencias Agropecuarias, Universidad Juárez Autónoma de Tabaco. Km. 25. Carretera Villahermosa-Teapa. CP. 86290. Centro, Tabasco, México. Email: efrain.delacruz@ujat.mx

How to cite this article: Felix, J.W., Sánchez-Chávez, E., de-laCruz-Lázaro, E. and Márquez-Quiroz, C. (2021). Edaphic and Foliar Biofortification of Common Black Bean (Phaseolus vulgaris L.) with Iron. Legume Research. 44(2): 192-196. DOI: 10.18805/LR-553.

Submitted: $24-02-2020 \quad$ Accepted: $28-04-2020$ Online: 28-07-2020

this work was to determine the effect of iron on the mineral content, proximal composition, bioactive compound content and antioxidant activity in the bean grain.

\section{MATERIALS AND METHODS}

The experiment was conducted at the nursery and greenhouse area of the Academic Division of Agricultural Sciences of the Juárez Autonomous University of Tabasco, in the municipality of Centro, Tabasco, Mexico; at $17^{\circ} 46^{\prime} 56^{\prime \prime}$ $\mathrm{N}, 92^{\circ} 57^{\prime} 28^{\prime \prime} \mathrm{W}$ and $21 \mathrm{~m} \mathrm{MSL}$.

Seed sowing was carried out in December 2018 using chromic luvisol soil, which was $\mathrm{pH} 5.6$, had an organic matter content of $2.9 \%$ and electrical conductivity of $53.5 \mu \mathrm{S} / \mathrm{cm}$. The soil contained $8.9 \mathrm{mg} / \mathrm{kg}$ iron and $1.9 \mathrm{mg} / \mathrm{kg}$ zinc. The distance between rows planted was $0.60 \mathrm{~m}$ and $0.20 \mathrm{~m}$ separated individual plants. Three seeds were deposited to 
ensure a planting density of 200,000 plants/hectare. Growth conditions were as follows: $11 \mathrm{~h}$ illumination under natural light at $28.5^{\circ} \mathrm{C}$ during the day and $19.5^{\circ} \mathrm{C}$ at night, relative humidity of $77 \%$ an average precipitation of $116 \mathrm{~mm}$. Creole bean seed ( $P$. vulgaris) was used and on average, plants required 44 days to flower and reached harvest maturity at 90 days after sowing. Fertilization was performed using 6446-00 kg/ha N-P-K formula fertilizer and the management of the crop was performed according to specifications of INIFAP (2017).

Twelve treatments that combined $0,0.25$ and $0.50 \mathrm{~g}$ edaphic doses of iron sulfate $\left(\mathrm{FeSO}_{4} \cdot 7 \mathrm{H}_{2} \mathrm{O}\right)$ with $0,25,50$ and $100 \mu \mathrm{M}$ foliar doses of iron chelate (EDDHA 6\%) were used. The edaphic applications were made directly to the soil at the time of plant emergence, pre-flowering and filling; while the foliar treatments were performed every 10 days from flowering to maturity, which totaled four applications periods.

Iron $(\mathrm{Fe})$, zinc $(\mathrm{Zn})$, copper $(\mathrm{Cu})$ and nickel $(\mathrm{Ni})$ content was quantified in the grains after each treatment and was repeated using atomic absorption spectrophotometry. While moisture, ash, crude fiber and fat content was determined using the methods described by AOAC (2000). Protein content was determined using the Dumas method (Armendáriz-Fernández et al., 2019). Further, carbohydrates were estimated using the formula:

$\%$ Carbohydrates $=100-($ Ash+Protein+Fat+Humidity $)$ and energy in Kcal $100 \mathrm{~g}^{-1}$ was determined using the formula: Energy $($ Kcal $)=$

$$
[(\text { fat } \times 9)+(\text { carbohydrates } \times 4)+(\text { protein } \times 4)] \text {. }
$$

The total phenolic content was determined using the spectrophotometric Folin-Ciocalteu method and concentrations were compared to a gallic acid standard curve that spanned 10 to $100 \mathrm{mg} / \mathrm{ml}$, results were reported in milligrams of gallic acid equivalents (GAE) per grams dry matter (mg GAE/g DM). Flavonoid content was quantified using a method proposed by Zhishen et al. (1999) and was reported in $\mathrm{mg}$ catechin equivalents per $\mathrm{g}$ per dry matter (mg CE/g DM). Anthocyanin content was measured via the differential $\mathrm{pH}$ method (Wrolstad, 1976) and content was reported in milligrams cyanidine-3-glucoside per $g$ of dry matter (mg C3G/g DM) and the percentage of antioxidant activity observed was determined via the DDPH method.

Data were analyzed using a randomized complete block design in a $3 \times 4$ factorial arrangement. The edaphic dose was the first factor and the foliar dose was the second. To determine differences between treatments, means were compared using the LSD test $(p<0.01)$. All analyses were performed using SAS 9.2 statistical software.

\section{RESULTS AND DISCUSSION}

Table 1 shows the mineral content of the $P$. vulgaris grains biofortified with iron. Statistical differences $(p<0.01)$ between individual and combined treatments are indicated. The iron content in beans subjected to edaphic application of iron increased from 57.35 to $64.82 \mathrm{mg} / \mathrm{kg}$, which was comparable with the highest iron content $(65.90 \mathrm{mg} / \mathrm{kg})$ obtained using the foliar application of $50 \mu \mathrm{M}$ iron. It is known that edaphic applications of iron are inefficient, because they are affected by the rapid and strong union of iron with soil particles, which prevent its absorption. This differs from reports that indicate that soil-based methods to apply of iron are not efficient, since they are affected by rapid and strong binding of iron and soil particles, which prevents its absorption (Fernández et al., 2015).

Statistical differences were observed between plants in edaphic iron doses for zinc and nickel content. Further, as iron dosage increased, the zinc content decreased, which is in accordance with observed antagonistic effects observed between the minerals previously (Głowacka et al., 2015). Plants subjected to foliar application of iron had different levels of iron and zinc than control-treated plants $(0 \mu \mathrm{M})$. The highest levels of iron were observed after treating plants with $50 \mu \mathrm{M}$ iron and as the concentration increased to 100 $\mu \mathrm{M}$, iron content decreased relative to the $50 \mu \mathrm{M}$ foliar dose, but remained increased relative to the control. The highest levels of iron observed after treating with $50 \mu \mathrm{M}$ iron is in accordance with findings of Márquez-Quiroz et al. (2015) who reported that doses producing the greatest increases in iron levels within Vigna unguiculata grains occurred after treating with $50 \mu \mathrm{M}$ of iron. Different results have been reported in the literature with regard to the effects of the foliar application of iron, maybe because penetration of solutions applied to leaves are controlled by complex mechanisms that depend on both environmental and

Table 1: Mineral content of Creole bean grains biofortified with iron.

\begin{tabular}{lclccl}
\hline Edaphic & Foliar & Iron & Zinc & Copper & Nickel \\
\cline { 3 - 6 } $\mathrm{G}$ & $\mu \mathrm{M}$ & \multicolumn{4}{c}{$\mathrm{mg} / \mathrm{kg}$} \\
\hline 0 & 0 & $51.00^{\mathrm{c}}$ & $24.87^{\mathrm{a}}$ & $10.80^{\mathrm{a}}$ & $7.72^{\mathrm{bc}}$ \\
0 & 25 & $55.57^{\mathrm{abc}}$ & $14.11^{\mathrm{bc}}$ & $9.90^{\mathrm{abc}}$ & $7.92^{\mathrm{abc}}$ \\
0 & 50 & $70.65^{\mathrm{ab}}$ & $22.22^{\mathrm{ab}}$ & $9.55^{\mathrm{abc}}$ & $7.66^{\mathrm{c}}$ \\
0 & 100 & $52.18^{\mathrm{c}}$ & $15.62^{\mathrm{bc}}$ & $9.94^{\mathrm{abc}}$ & $7.78^{\mathrm{abc}}$ \\
0.25 & 0 & $61.08^{\mathrm{abc}}$ & $15.30^{\mathrm{bc}}$ & $8.67^{\mathrm{c}}$ & $8.02^{\mathrm{abc}}$ \\
0.25 & 25 & $66.57^{\mathrm{abc}}$ & $15.63^{\mathrm{bc}}$ & $10.20^{\mathrm{ab}}$ & $7.92^{\mathrm{abc}}$ \\
0.25 & 50 & $59.55^{\mathrm{abc}}$ & $11.06^{\mathrm{c}}$ & $9.35^{\mathrm{abc}}$ & $8.39^{\mathrm{ab}}$ \\
0.25 & 100 & $72.07^{\mathrm{a}}$ & $11.35^{\mathrm{c}}$ & $9.64^{\mathrm{abc}}$ & $8.39^{\mathrm{ab}}$ \\
0.5 & 0 & $53.40^{\mathrm{c}}$ & $15.38^{\mathrm{bc}}$ & $9.95^{\mathrm{abc}}$ & $8.03^{\mathrm{abc}}$ \\
0.50 & 25 & $54.15^{\mathrm{bc}}$ & $13.37^{\mathrm{c}}$ & $9.05^{\mathrm{bc}}$ & $8.23^{\mathrm{abc}}$ \\
0.50 & 50 & $67.50^{\mathrm{abc}}$ & $7.60^{\mathrm{c}}$ & $10.55^{\mathrm{a}}$ & $8.46^{\mathrm{a}}$ \\
0.50 & 100 & $56.90^{\mathrm{abc}}$ & $8.74^{\mathrm{c}}$ & $9.97^{\mathrm{abc}}$ & $8.26^{\mathrm{abc}}$ \\
Edaphic & 0 & $57.35^{\mathrm{a}}$ & $19.20^{\mathrm{a}}$ & $10.05^{\mathrm{a}}$ & $7.77^{\mathrm{b}}$ \\
& 0.25 & $64.82^{\mathrm{a}}$ & $13.34^{\mathrm{b}}$ & $9.46^{\mathrm{a}}$ & $8.18^{\mathrm{a}}$ \\
& 0.50 & $57.98^{\mathrm{a}}$ & $11.27^{\mathrm{b}}$ & $9.88^{\mathrm{a}}$ & $8.24^{\mathrm{a}}$ \\
Foliar & 0 & $55.16^{\mathrm{b}}$ & $18.52^{\mathrm{a}}$ & $9.81^{\mathrm{a}}$ & $7.92^{\mathrm{a}}$ \\
& 25 & $58.76^{\mathrm{ab}}$ & $14.37^{\mathrm{ab}}$ & $9.72^{\mathrm{a}}$ & $8.02^{\mathrm{a}}$ \\
& 50 & $65.90^{\mathrm{a}}$ & $13.63^{\mathrm{ab}}$ & $9.82^{\mathrm{a}}$ & $8.17^{\mathrm{a}}$ \\
& 100 & $60.38^{\mathrm{ab}}$ & $11.90^{\mathrm{b}}$ & $9.85^{\mathrm{a}}$ & $8.14^{\mathrm{a}}$ \\
\hline
\end{tabular}

Different letters within the column indicate statistical differences that were determined using the LSD test $(p \leq 0.01)$. 
Edaphic and Foliar Biofortification of Common Black Bean (Phaseolus vulgaris L.) with Iron

Table 2: Proximal composition of biofortified Creole bean grains with iron.

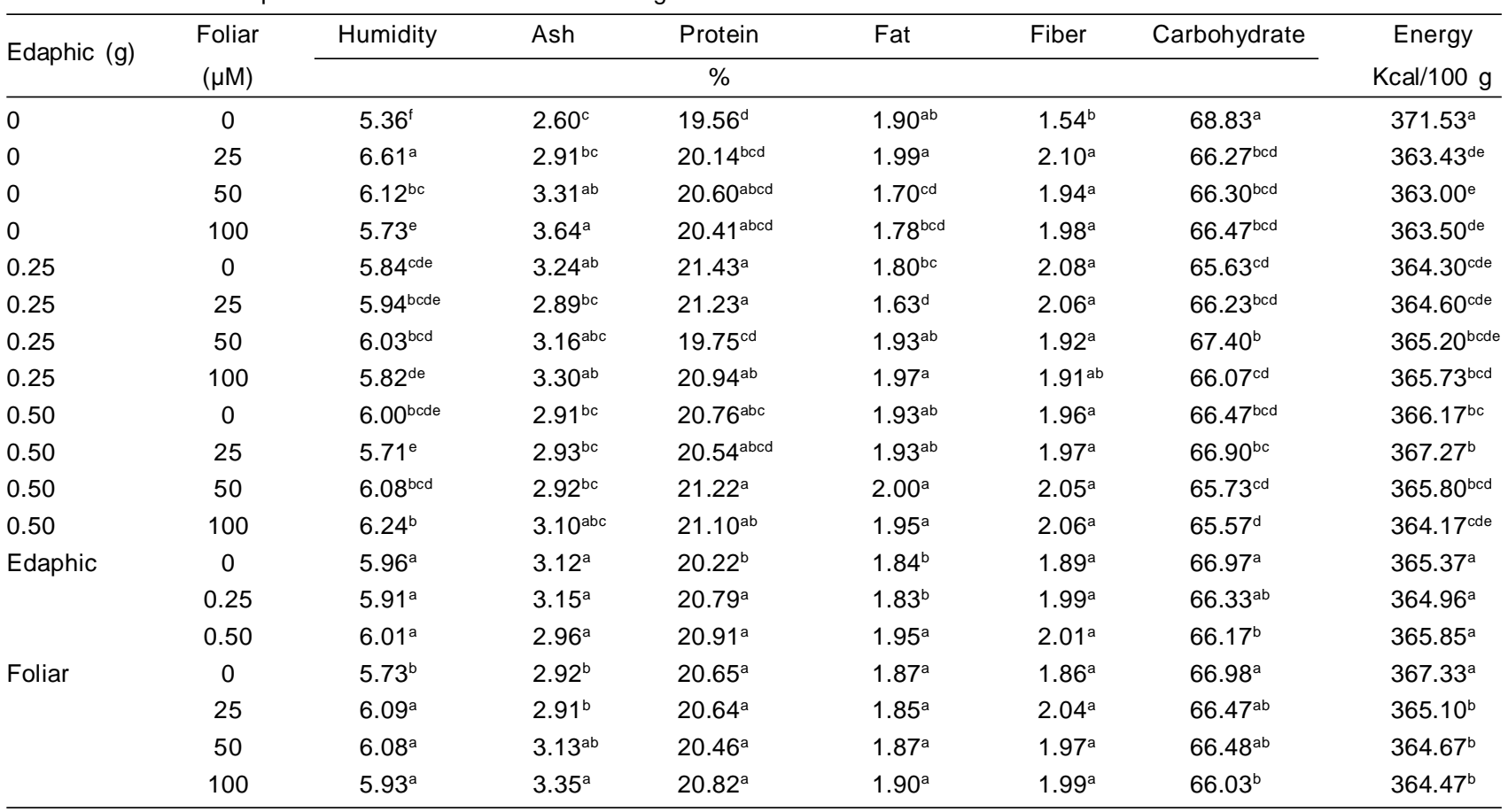

Different letters within the column indicate statistical differences according to the LSD test $(p \leq 0.01)$.

biological factors (Fernández et al., 2015). Previously, the highest levels of zinc content were observed in control plants. Further, as different doses of edaphic or foliar iron, concentrations of other minerals decreased as a result of antagonistic effects (Głowacka et al., 2015).

When comparing different combinations of edaphic and foliar treatments statistical differences between mineral levels were observed $(p \leq 0.01)$. The highest levels of iron were observed in plants treated with $0.25 \mathrm{~g}$ edaphic and $100 \mu \mathrm{M}$ foliar iron $(72.07 \mathrm{mg} / \mathrm{kg})$, followed by $0 \mathrm{~g}$ edaphic and $50 \mu \mathrm{M}$ foliar iron $(70.65 \mathrm{mg} / \mathrm{kg})$. The combination $0 \mathrm{~g}$ edaphic and $0 \mu \mathrm{M}$ foliar iron (control treatment) produced the lowest iron content $(51 \mathrm{mg} / \mathrm{kg})$. The two combinations that resulted in the production of plants with the greatest iron content improved levels observed within controls by 41.30 and $38.50 \%$, respectively. Values that greater than the $29 \%$ are greater than levels reported in beans biofortified with iron in Sida-Arreola et al. (2015). With regard to levels of zinc, it was observed that as the iron dose increases, zinc levels decrease. Accordingly, Głowacka et al. (2015) reported an antagonistic effect between the minerals. The highest levels of copper were observed in control plants, while all combinations of edaphic or foliar doses of iron functioned to decrease copper content. However, control plants had low levels of nickel and combinations of iron treatments tended to increase nickel levels. A combinations $0.50 \mathrm{~g}$ edaphic and $50 \mu \mathrm{M}$ foliar iron produced plants with the highest levels of nickel $(8.26 \mathrm{mg} / \mathrm{kg})$.

When edaphic application of iron was performed, statistical differences $(p \leq 0.01)$ between control and treated plants with regard protein, fat and carbohydrate content were observed (Table 2). When foliar application of iron was performed, statistical differences $(p \leq 0.01)$ between control and treated plants were observed with regard to humidity, ash, carbohydrates and energy levels. By increasing the edaphic dosage of iron, protein and fat content increased. When foliar application of iron was performed, moisture and ash content increased. Foliar application showed corresponded with decreased carbohydrate and energy levels, effects that were also observed after applying iron via the soil. It was observed that as both edaphic and foliar iron dose increased, moisture, ash and crude fiber content increased relative to controls. Increase in edaphic or foliar combinations of iron treatments also increased the ash $(2.91$ to $3.64 \%$ ), protein (19.75 to $21.43 \%$ ) and crude fiber (1.91 to $2.1 \%$ ) content. The high ash content observed after treatment using combinations of foliar and edaphic iron indicates increased iron enhances mineral content within grains, while the high protein content observed may be related to increases in iron content obtained (Table 1). Cakmak et al. (2010) and Zielińska-Dawidziak (2015) reported that the ability to accumulate iron depends on grain protein levels. Crude fiber content was 1.54 and $2.10 \%$ in plants treated with combinations of iron treatments. Treatment produced fiber levels that were higher than control values, which indicated that iron enhances raw fiber content (Brigide et al., 2014). The control had the highest levels of carbohydrates and energy $(68.83 \%$ and $371.53 \mathrm{Kcal} / 100 \mathrm{~g})$, while the edaphic or foliar iron combinations decreased content relative to control values.

Bioactive compounds like anthocyanins were significantly affected $(p \leq 0.01)$ by edaphic application of iron. 
Edaphic and Foliar Biofortification of Common Black Bean (Phaseolus vulgaris L.) with Iron

Table 3: Bioactive compound content and antioxidant activity of biofortified Creole bean grains with iron.

\begin{tabular}{|c|c|c|c|c|c|}
\hline Edaphic (g) & $\begin{array}{l}\text { Foliar } \\
(\mu \mathrm{M})\end{array}$ & $\begin{array}{c}\text { Total phenols } \\
\text { (mg GAE/g DM) }\end{array}$ & $\begin{array}{c}\text { Flavonoids } \\
\text { (mg CE/ g DM) }\end{array}$ & $\begin{array}{c}\text { Anthocyanins } \\
\text { (mg EC3G/g extract) }\end{array}$ & $\begin{array}{l}\text { Antioxidant } \\
\text { Activity (\%) }\end{array}$ \\
\hline 0 & 0 & $3.85^{\mathrm{e}}$ & $0.89^{b c}$ & $0.76^{e}$ & $86.82^{\mathrm{ab}}$ \\
\hline 0 & 25 & $5.49^{\mathrm{bcd}}$ & $1.03^{b}$ & $1.64^{\mathrm{a}}$ & $86.84^{\mathrm{ab}}$ \\
\hline 0 & 50 & $6.75^{\mathrm{ab}}$ & $0.71^{\text {bcde }}$ & $1.43^{\mathrm{abc}}$ & $85.13^{\mathrm{abcd}}$ \\
\hline 0 & 100 & $6.06^{\mathrm{abc}}$ & $0.96^{b}$ & $1.39^{a b c d}$ & $84.36^{\mathrm{abcd}}$ \\
\hline 0.25 & 0 & $6.18^{a b c}$ & $1.53^{a}$ & $1.48^{\mathrm{ab}}$ & $89.76^{a}$ \\
\hline 0.25 & 25 & $4.40^{\mathrm{de}}$ & $0.82^{\mathrm{bcd}}$ & $0.89^{\text {cde }}$ & $86.66^{\mathrm{ab}}$ \\
\hline 0.25 & 50 & $7.37^{a}$ & $0.49^{\mathrm{de}}$ & $1.37^{\mathrm{abcd}}$ & $79.63^{d}$ \\
\hline 0.25 & 100 & $5.12^{\text {cde }}$ & $0.97^{b}$ & $1.32^{\mathrm{abcd}}$ & $80.66^{\mathrm{cd}}$ \\
\hline 0.50 & 0 & $6.60^{\mathrm{ab}}$ & $0.56^{\text {cde }}$ & $1.14^{\mathrm{abcde}}$ & $85.42^{\mathrm{abc}}$ \\
\hline 0.50 & 25 & $5.74^{\mathrm{bcd}}$ & $0.54^{\text {cde }}$ & $0.91^{\text {cde }}$ & $81.23^{\mathrm{bcd}}$ \\
\hline 0.50 & 50 & $4.99^{\text {cde }}$ & $0.42^{\mathrm{e}}$ & $0.86^{\mathrm{de}}$ & $84.96^{\mathrm{abcd}}$ \\
\hline 0.50 & 100 & $5.94^{\mathrm{abc}}$ & $0.41^{\mathrm{e}}$ & $0.97^{\text {bcde }}$ & $86.69^{a b}$ \\
\hline \multirow[t]{3}{*}{ Edaphic } & 0 & $5.54^{a}$ & $0.90^{a}$ & $1.30^{a}$ & $85.79^{a}$ \\
\hline & 0.25 & $5.77^{a}$ & $0.95^{a}$ & $1.27^{\mathrm{a}}$ & $84.57^{a}$ \\
\hline & 0.50 & $5.82^{a}$ & $0.49^{b}$ & $0.97^{b}$ & $84.18^{a}$ \\
\hline \multirow[t]{4}{*}{ Foliar } & 0 & $5.21^{\mathrm{b}}$ & $0.99^{a}$ & $1.13^{a}$ & $87.33^{a}$ \\
\hline & 25 & $5.54^{b}$ & $0.80^{a}$ & $1.15^{\mathrm{a}}$ & 84.91 ab \\
\hline & 50 & $6.37^{a}$ & $0.78^{a}$ & $1.22^{a}$ & $83.24^{b}$ \\
\hline & 100 & $5.71^{\mathrm{ab}}$ & $0.54^{b}$ & $1.23^{a}$ & $83.90^{b}$ \\
\hline
\end{tabular}

Different letters within the column indicate statistical differences according to the LSD test $(p \leq 0.01)$.

Further, foliar forms produced statistical differences in total phenol and flavonoid content and antioxidant activity (Table 3). The highest total levels of phenolics were obtained post-treatment with $50 \mu \mathrm{M}$ of iron chelate and decreased levels of phenolics were observed when plants were treated with $100 \mu \mathrm{M}$ iron chelate. Edaphic applications of iron also increased levels of phenolics, but observed increases were not statistically significant. Phenolic compounds in food have important effects on human health. These effects are due to their antioxidant, anti-inflammatory, antiviral and anticancer properties (Cevallos-Casals and CisnerosZevallos, 2010). The highest level of total phenolic was produced by treating plants with $50 \mu \mathrm{M}$ iron. With a combination of methods were used to treat plants, total phenolic content varied between 3.85 and $7.37 \mathrm{mg} \mathrm{GAE} / \mathrm{g}$ $\mathrm{DM}$ and all doses assessed produced levels that were higher those of controls. A combination $0.25 \mathrm{~g}$ edaphic and $50 \mu \mathrm{M}$ foliar iron produced plants with the greatest phenolic content. In general, phenolic content in plants treated with all combinations of iron applications were greater than 2.11 $\mathrm{mg} \mathrm{GAE} / \mathrm{g}$ DM total phenolics, which was previously reported in black beans (Chávez-Mendoza and Sánchez, 2017). This finding indicated that iron application enhances phenolic content and may have been a result of stress produced by treatments, since production of phenolics compounds are controlled by secondary metabolic pathways that respond to ecological and physiological stress within plants (Lattanzio, 2013).

Flavonoid levels were affected by edaphic and foliar doses of iron to degrees that differed statistically. Further, higher iron doses resulted in the lowest levels of flavonoids.
The combinations of treatments also significantly affected catechin levels, producing levels that varied between 0.41 and $1.53 \mathrm{mg} \mathrm{CE} / \mathrm{g} \mathrm{DM}$. Treatment with $0.50 \mathrm{~g}$ edaphic and $50 \mu \mathrm{M}$ foliar iron and $0.50 \mathrm{~g}$ edaphic and $100 \mu \mathrm{M}$ foliar iron resulted in the greatest iron content; these levels significantly decreased flavonoid levels. This was in accordance with effects of individual edaphic and foliar doses of iron in which decreased flavonoid levels were observed as dose increased. Statistical differences in anthocyanin levels were observed when edaphic application of iron was performed. Further, 0 and $0.25 \mathrm{~g}$ doses produced plants with the highest levels of anthocyanins. Foliar application of iron did not produce statistically altered levels of anthocyanins, however levels tended to increase with the iron dose. When combination of application types was assessed, values between 0.76 and $1.64 \mathrm{mg}$ EC3G/g anthocyanins extract were determined and the lowest value corresponded to control value. In general, anthocyanin content determined was similar to that which was reported by ArmendárizFernández et al. (2019), who assessed varieties of Mexican beans. The combinations producing the greatest levels of anthocyanins that were within the range of dosages reported hare included $0 \mathrm{~g}$ edaphic and $25 \mu \mathrm{M}$ foliar iron, $0.25 \mathrm{~g}$ edaphic and $0 \mu \mathrm{M}$ foliar iron and $0 \mathrm{~g}$ edaphic - $25 \mu \mathrm{M}$ foliar iron.

The antioxidant activities of plants provided different combination of iron treatments ranged from 79.63 to $89.76 \%$. the greatest activities were observed in plants that were provided a combination $0.25 \mathrm{~g}$ edaphic and $0 \mu \mathrm{M}$ foliar iron, which was statistically similar to the antioxidant activities produced by providing the eight combinations, including the control. Accordingly, Armendáriz-Fernández et al. (2019) 
reported antioxidant activities of black beans were similar to those determined in this work. Treatment with combination $0.25 \mathrm{~g}$ edaphic and $100 \mu \mathrm{M}$ foliar iron resulted in the greatest levels of iron the lowest antioxidant activities. Similar trends were observed when edaphic and foliar iron were applied individually. The negative correlation observed between iron and antioxidant activity may be due to the fact that iron is a pro-oxidant metal that affects antioxidant activity (Perron and Brumaghim, 2009).

\section{CONCLUSION}

Bean biofortification with edaphic doses of iron sulfate and iron chelate foliates both influences the mineral content, proximal composition, bioactive compounds and antioxidant activity of the grain. The highest levels of iron were produced by treating with combinations of $0.25 \mathrm{~g}$ edaphic and $100 \mu \mathrm{M}$ foliar iron and $0 \mathrm{~g}$ edaphic and $50 \mu \mathrm{M}$ foliar iron. In general, all combinations of treatment that provided iron increased ash, fat, proteins, crude fiber, total phenols and anthocyanins content, while carbohydrate and energy content decreased as iron levels increased. The highest antioxidant activities were produced by providing any of nine combinations of treatment, which included the control combination and produced antioxidant activities of $84.96-89.76 \%$.

\section{REFERENCES}

AOAC. (2000). Official methods of analysis of AOAC International. $17^{\text {th }}$ ed. Association of Official Analytical Chemist. Oakville, MD, USA.

Armendáriz-Fernández, K.V., Herrera-Hernández, I.M., MuñozMárquez, E., Sánchez, E. (2019). Characterization of bioactive compounds, mineral content and antioxidant activity in bean varieties grown with traditional methods in Oaxaca, Mexico. Antioxidants. 8: 26. Doi: 10.3390/ antiox8010026.

Brigide, P., Canniatti-Brazaca, S.G., Silva, M.O. (2014). Nutritional characteristics of biofortified common beans. Food Science and Technology. 34(3): 493-500.

Cakmak, I., Pfeiffer, W.H., McClafferty, B. (2010). Review: Biofortifi-cation of durum wheat with zinc and iron. Cereal Chemistry. 87(1):10-20.

Cevallos-Casals, B.A. and Cisneros-Zevallos, L. (2010). Impact of germination on phenolic content and antioxidant activity of 13 edible seed species. Food Chemistry. 119(4): 14851490.

Chávez-Mendoza, C. and Sánchez, E. (2017). Bioactive compounds from mexican varieties of the common bean (Phaseolus vulgaris): Implications for health. Molecules. 22. Doi: 10.3390/molecules22081360.

Connorton, J.M. and Balk, J. (2019). Iron biofortification of staple crops: Lessons and challenges in plant genetics. Plant Cell Physiology. 60(7): 1447-1456.

Fernández, V., Sotiropoulos, T., Brown, P. (2015). Fertilización foliar: Principios científicos y práctica de campo. Primera Edición. Asociación Internacional de la Industria de Fertilizantes. Paris, Francia. pp. 156.

Głowacka, A., Klikocka, H., Onuch, J. (2015). Content of zinc and iron in common bean seeds (Phaseolus vulgaris L.) in different weed control methods. Journal of Elementology. 20(2): 293-303.

INIFAP. (2017). Agenda técnica agrícola de Tabasco. Instituto Nacional de Investigaciones Forestales, Agrícolas y Pecuarias. México. pp 140.

Lattanzio V. (2013). Phenolic compounds: Introduction. In: Handbook Natural Products [Ramawat, K. and Mérillon, J.M. (eds)]. Springer, Berlin, Heidelberg. pp. 1543-1580.

Márquez-Quiroz, C., De la Cruz-Lázaro, E., Osorio-Osorio, R., Sánchez-Chávez, E. (2015). Biofortification of cowpea beans with iron: iron's influence on mineral content and yield. Journal of Soil Science and Plant Nutrition. 15(4): 839-847.

Nissar, R., Zahida, R., Kanth, R.H., Manzoor, G., Shafeeq, R., Ashaq, H., Waseem, R., Bhat, R.A., Bhat, M.A, Tahir, S. (2019). Agronomic biofortification of major cereals with zinc and iron- A review. Agricultural Reviews. 40(1): 21-28.

Perron, N.R. and Brumaghim, J.L. (2009). A Review of the antioxidant mechanisms of polyphenol compounds related to iron binding. Cell Biochemistry and Biophysics. 53: 75-100.

Petry, N., Egli, I., Gahutu. J.B., Tugirimana, P.L., Boy, E., Hurrell, R. (2014). Phytic acid concentration influences iron bio-availability from biofortified beans in Rwandese women with low iron status. The Journal of Nutrition. 144(11): 1681-1687.

Rani, T.S., Kumar, G.A., Sravanti, K., Kumar, C.V.S., Maheswaramma, S., Ramesh, S., Parimal, M. (2019). Heterosis effects on genetic biofortification of grain iron and zinc in pearl millet (Pennisetum glacum L.). Indian Journal of Agricultural Research. 53(6): 655-661.

Shukla, U.N. and Lata, M.M. (2018). Biofortification: Golden way to save life from micronutrient deficiency- A review. Agricultural Reviews. 39(3): 202-209.

Sida-Arreola, J.P., Sánchez-Chávez, E., Ávila-Quezada, G.D., Zamudio-Flores, P.B., Acosta-Muñíz, C.H. (2015). Iron biofortification and its impact on antioxidant system, yield and biomass in common bean. Plant Soil Environment. 61(12): 573-576.

Sperotto, R.A. and Ricachenevsky, F.K. (2017). Common bean Fe biofortification using model species' lessons. Frontiers in Plant Sciences. 8: Article 2187. Doi: 10.3389/fpls.2017. 02187.

Wrolstad, R.E. (1976). Color and pigment analyses in fruit products. Oregon State University. Station Bulletin. 624: 1-7.

Zhishen, J., Mengcheng, T., Jianming, W. (1999). The determination of flavonoid contents in mulberry and their scavenging effects on superoxide radicals. Food Chemistry. 64(4): 555-559.

Zielińska-Dawidziak, M. (2015). Plant ferritin-A source of iron to prevent its deficiency. Nutrients. 7(2): 1184-1201. 